\title{
The Riskiness of Risk Models: Assessment of Bankruptcy Risk of Non-Financial Sector of Pakistan
}

\author{
Usama Ehsan Khan ${ }^{1}$, Javed Iqbal' ${ }^{2}$, Syed Faizan Iftikhar ${ }^{3}$
}

\begin{abstract}
Bankruptcy prediction has long been an important concern for various stakeholders in an increasingly intricated business environment. Using a sample of 3,806 company-year observations of listed non-financial companies of Pakistan during 2005-2015, the paper compares models and identifies an optimal approach in terms of forecasting accuracy for predicting financial distress and bankruptcy. The purpose of the study is to develop a model with relatively high predictability and figure out determinants of bankruptcy. By employing financial ratios, equity market variables and macroeconomic indicators; the hybrid artificial neural network (ANN) validates superior performance as opposed to dynamic panel probit and Merton (1974) models individually. Among financial ratios; quick ratio, cash ratio, current to total asset, quick to total asset, cash flow to short-term debt, gross profit margin, asset turnover, interest to debt, net working capital to net sales, and cash to net sales are crucial in examining firm's financial status. Additionally, money supply, forex reserves, exchange rate, balance of trade, and real GDP growth rate are found statistically meaningful in predicting bankruptcy.
\end{abstract}

Keywords: Bankruptcy prediction, credit risk, hybrid-ANN, Dynamic Binary Panel Probit JEL classification: C25, C45, G30, G33

\section{Introduction}

Bankruptcy is the legal status of a business entity reflecting a sobering economic reality of corporate or financial institutions which is the likely outcome of financial distress. Given the dynamic nature of the characteristics of financially distressed firms, it is essential for stakeholders and practitioners to examine different aspects of bankruptcy and enhance the performance of existing bankruptcy prediction models. Bankruptcy or failure is defined as "the inability of a firm to pay its financial obligations

$1 \mathrm{PhD}$ candidate at Applied Economics Research Centre, University of Karachi,

Email: usama.ehsan@gmail.com

2 Associate Professor, Institute of Business Administration, Karachi, Email: jiqbal@iba.edu.pk

3 Assistant Professor, Applied Economics Research Centre, University of Karachi, mail: faizanburney@aerc.edu.pk

\begin{tabular}{ll} 
ARTICLE HISTORY & \\
01 Jul, 2019 Submission Received & 31 Aug, 2019 First Review \\
\hline 03 Jan, 2020 Second Review & 13 May, 2020 Third Review \\
\hline 30 May, 2020 Accepted
\end{tabular}

30 May, 2020 Accepted 
as they mature" (Beaver, 1966, p. 71). The financial distress arises when a company has mostly illiquid assets, high fixed costs, or revenue sources that are exposed to the business cycle which ultimately leads toward bankruptcy. Financial distress proxy default risk and the lender would ask for an additional premium to compensate that risk. The other related terms found in the literature include failure, insolvency, and default. We use these terms interchangeably as in previous studies (Altman \& Hotchkiss, 2006).

Suboptimal provision of resources because of the faulty prediction of the creditworthiness of counterparty can incur significant losses. A classic example to this end is the sub-prime mortgage crisis of 2007-08 which bankrupted even venerable banks and companies like Lehman Brothers, Washington Mutual, General Motors, etc. The predictive ability of traditional financial distress prediction appears limited during the period of the Global Financial Crisis of 2007-08 (Ashraf, Felix, \& Serrasqueiro, 2019). Bankruptcy prediction has attracted researchers since the work of Beaver (1966) and Altman (1968). In early prediction models, financial statements of the companies are considered as the only source in assessing the financial position of the company. Later studies, however, include equity market characteristics and macroeconomic variables as prospective predictors. Ohlson (1980) uses financial ratios to forecast bankruptcy and also highlights the significance of equity market variables in reviewing financial status. Agarwal and Taffler (2008) argue that stock prices reflect all information in financial statements and contain additional information. Other studies including Tinoco, Holmes, and Wilson (2015), and Tinoco and Wilson (2013) conclude that utilization of financial ratios, stock market variables, and macroeconomic indicators simultaneously can enhance forecasting accuracy. Following previous studies, the current study argues that the financial health of the firm primarily contingent on three sources of risk which firstly include the firm's idiosyncratic characteristics like profitability, liquidity, efficiency, and solvency which can be proxied through financial ratios. Economic conditions and business cycle positioning are also relevant in examining bankruptcy, therefore, macroeconomic variables are employed. Besides, equity market variables are considered forward-looking and reflect investor's perception toward the financial conditions of the firm, therefore, these variables are also expected to enhance the predictive performance of the model.

Bankruptcy risk is highly pronounced in developing countries. It has been argued that sovereign risk is associated with an aggregate default risk of a country's corporate sector (Altman \& Rijken, 2011). Pakistan is among those countries that are critical to default risk as international rating agencies like Moody and Fitch have downgraded Pakistan's long-term debt rating from 'stable' to 'negative' outlook in the third quarter of 2018. Persistent economic and political turmoil along with the absence of 
stringent bankruptcy laws has also heightened the cost of doing business. The huge failure of textile firms in Pakistan in the late 2000s brings concrete evidence. About 0.2 million power looms and at least 40 percent of Pakistan's textile industry have either fled to Bangladesh or shut down their businesses over 2007-2012. Therefore, it is imperative to assess the prevailing financial conditions of the non-financial sector in Pakistan as there is no effective legitimate business protection available. Moreover, no international study particularly focuses on Pakistan that evaluates the causes and effects of the bankruptcies.

A large number of models and corresponding methodologies have evolved for detecting financial distress, however, the problem of developing an optimal approach still stands. The current study is devoted to identifying an optimal model for examining the financial distress of the non-financial sector of Pakistan. These models include dynamic panel probit, hybrid artificial neural network, and Merton's (1974) model which are carefully selected in such a way that each model captures a distinct underlying aspect.

This paper contributes to the existing literature in numerous ways. It firstly focuses on the Pakistani non-financial sector over the period of 2005-2015 and classifies firms between bankrupt versus non-bankrupt by combining finance-based definition along with legal bankruptcy classification. Pakistan has a diversified industrial base that particularly includes textile, food, pharmaceutical, paper and paper board, and other industries. Moreover, the strategic ties between China and Pakistan have touched its peak with a visible economic expansion in the wake of the China Pakistan Economic Corridor (CPEC) project. Therefore, insights pertaining to business risk characteristics in Pakistan and the identification of an optimal approach to assess the same is an interest of various stakeholders.

Second, it appears that firms with financial complexities in previous years are more likely to get bankrupt thus autoregressive scheme seems reasonable. Therefore, the dynamic panel probit model of Wooldridge (2005) is employed for the first time in evaluating bankruptcy. Further, data science is an emerging technology and models like Artificial Neural Networks (ANNs) have been widely reported for their appealing accuracy. Unlike traditional statistical methods such as Multiple Discriminant Analysis (MDA), ANN is not grounded on stringent statistical assumptions but suffers from overfitting problems when there are more explanatory variables (Khemakhem $\&$ Boujelbene, 2018). The integration of dynamic panel probit model and ANN (i.e. hybrid-ANN) controls an issue of overfitting while retaining higher predictability of ANN. Hybrid-ANN is the second model of the study and this study extends the relevant literature by providing hybridization of two approaches for predicting bankruptcy. In addition, the third model (i.e. Merton-model) of the study is a simplified 
version of Moody's-KMV- a proprietary model of Moody's Analytics- and can be viewed as of practical significance. Many studies (such as Gharghori, Chan \& Faff, 2007; Agarwal, \& Taffler, 2008; Vassalou \& Xing, 2004) argue about the widespread success of Merton model.

Finally, using a panel framework along with three types of variables i.e. financial ratios, macroeconomic variables, and equity market variables simultaneously (similar to Tinoco \& Wilson, 2013) add value to the existing literature.

The results of the study broaden the existing literature in the following ways. Financial ratios and macroeconomic variables are found statistically significant while equity market variables failed to add any value in predicting bankruptcy. The poor predictability of equity market variables raises concerns over stock market efficiency and brings evidence of mispricing of default risk in equity returns. The hybrid ANN model (i.e. a combination of ANN and dynamic panel probit model) attained the highest predictive accuracy for both in-sample and out-of-sample forecasts. Both models are complementary as a dynamic panel model provides interpretability of the coefficient while hybrid ANN enhanced the forecasting accuracy. Moreover, the study provides a material definition of bankruptcy for the non-financial sector of Pakistan.

The rest of the study is structured as follows. Section 2 provides a review of existing literature. Section 3 is the research design. Section 4 describes the empirical results. Section 5 exhibits model diagnostic and, finally, Section 6 presents the conclusion.

\section{Review of Literature}

Most of the previous studies employ a legal definition of bankruptcy and are modelled through binary choice models based on a distinctive population of bankrupt and non-bankrupt companies. However, a legal definition has some limitations. For instance, the bankruptcy filing does not guarantee insolvency, it may be seeking temporary protection and vice versa may also be true (Haber, 2011). Moreover, a legal filling can be a lengthy and costly process and may not be representative of a true economic event of failure. In the context of Pakistan, a plethora of ineffective and flawed bankruptcy laws are prevailing while businesses are at their own risk. Hasanain and Shah (2012) examine the Corporate Rehabilitation Act (CRA) (Securities and Exchange Commission of Pakistan, 2009d) and found it defective as well as more debtors' friendly rather than optimal. A recent study of Luqman, Hassan, Tabasum, Khakwani, and Irshad (2018) defines financial distress as the situation when a firm generates negative income in the previous five years consistently for non-financial firms of Pakistan. Their study ignores legal classification, moreover, employed definition narrowed down a very small sample. The current study, therefore, uses the 
definition for quoted companies in Pakistan by combining finance-based definitions along with legal bankruptcy classification. The utility of finance-based definition has been marked significant in the academic literature (Pindado, Rodrigues, $\&$ de la Torre, 2008; Tinoco et al., 2015) and supported by the fact that financial distress is more accurately and timely pronounced in financial statements before legal proceedings. The study contributes to the existing literature by the integration of legal and finance-based definition in contrast to individual independent definitions utilized in previous studies.

The lack of theoretical underpinning for bankruptcy has limited the development of a sound scientific approach to bankruptcy prediction while a wide range of empirical frameworks is available. The extensive bankruptcy literature encompasses a variety of methodologies ranging from statistical to data science models. The modelling of financial distress for quoted companies is dated back to two centuries (Altman \& Hotchkiss, 2006). Empirical literature mainly emerges after the seminal work of Beaver (1966) followed by Altman (1968). Beaver (1966) studies the predictive abilities of financial statements by using univariate analysis. Altman's (1968) work employed multiple ratios simultaneously with the help of Multiple Discriminant Analysis (MDA). The conditional logit, firstly employed by Ohlson (1980) to generate the probability of default followed by many others (such as Campbell, Hilscher, \& Szilagyi, 2008). Shumway (2001) introduces the simple hazard model (similar to multi-period logit) and finds significant improvement in accuracy employing dynamic version. Rashid and Abbas (2011) construct Z-score for Pakistan by modelling financial ratios via MDA. Khan (2018) reveals that the logit model outperforms discriminant analysis in analyzing bankruptcy for the financial sector of Pakistan.

Data science approaches (such as ANN, support vector machines, decision trees, and others) have emerged as a new challenger for traditional statistical models since the 1990s. Altman, Marco, and Varetto (1994) compare linear discriminant analysis (LDA) with ANN. They accept the high predictive ability of ANN but cautious about the architecture of the network. Other studies focus on hybrid-ANN models, such as Lee, Han, and Kwon (1996) hybridize ANN with statistical models like MDA, decision tree algorithm and self-organizing feature map (SOFM) model. Moreover, Jo and Han (1996) integrate ANN by using probabilities of default from different models and utilize them as an input layer in ANN. A recent study of Alaka, Oyedele, Owolabi, Kumar, Ajayi, Akinade, and Bilal (2018) review statistical and artificial intelligence tools in an attempt to identify the model with superior performance. It is argued that hybrid models tend to outperform individual predictive approaches. Beaver, Cascino, Correai, and McNichols (2019) employ a two-pronged methodology by first estimating the discrete hazard model and a non-parametric approach (i.e. 
Classification and Regression Tree) in the second stage. An interesting study of Mai, Tian, Lee, and Ma (2019) apply deep learning models (i.e. average embedding model and convolutional neural network) for predicting bankruptcy which uses textual data (from Management Discussion and Analysis (MD\&A)) in conjunction with accounting and market-based variables.

In contrast to purely empirical methodologies, modern structural default risk models are backed by theory. It explains the likelihood of corporate failure by equity market information solely. One of the popular models in this context stems from Black and Scholes (1973), and Merton's (1974) working on option pricing - recognizes as Merton's model. Various studies like Gharghori et al. (2007), Agarwal and Taffler (2008), Bharath and Shumway (2008), and Vassalou and Xing (2004) utilize Merton's model for finding probabilities of default. Previous studies also tested modelling performance based on types of variables. The relative contribution of three types of variables (i.e. market variables, macroeconomic indicators and financial ratios) is more generally tested in many studies. These studies (Tinoco et al., 2015; Pindado et al., 2008) have concluded a higher predictive ability than those employing financial variables alone. Beaver et al. (2019) use financial ratios, macroeconomic variables, and country-specific variables for group affiliated firms.

Previous studies have not tested dynamic panel probit and hybrid empirical methodologies in the context of Pakistan. Moreover, existing bankruptcy studies have also not included macroeconomic and market-based variables simultaneously along with financial ratios to figure out determinants of bankruptcy in Pakistan. This study aims to fill this gap by testing competitive modelling approaches and identifying statistically meaningful determinants of bankruptcy for the non-financial sector of Pakistan.

\section{Data and Methodology}

This section aims to view the dataset, the definition of dependent variables, independent variables, and models to be employed.

\subsection{Dataset}

The data taken for the study is comprised of 346 non-financial publicly quoted companies for the period over 2005-2015. The available financial ratios are taken from Financial Statement Analysis of publicly traded non-financial companies- published by the State Bank of Pakistan. The macroeconomic variables are obtained from Datastream and the stock market-based information is taken from Bloomberg.

The existence of extreme values of variables can potentially distort the results. 
This study winsorises ${ }^{4}$ all variables/ratios (except macroeconomic) at a $5 \%$ level across all firms. That is, the time series of each firm is replaced by the lowest (highest) $5 \%$ with the $0.05(0.95)$ quantile on each variable similar to Bauer (2012). However, the current study winsorises time series of each firm using the pooled data set. There is no further data manipulation. Other studies like Tinoco and Wilson (2013) used 'tangent-hyperbolic' transformation while winsorise at 90\%.

\subsubsection{Definition of the dependent variable}

This section discusses the definition of the dependent variable. The study combines legal bankruptcy classification with finance-based definition by employing the following conditions:

1. Companies that are deemed to be defaulted in 2015 or later. The intuition is that the companies that are defaulted in 2015, 2016, or 2017, must have financial distress in the previous years ${ }^{5}$.

2. Following Pindado et al. (2008), the firm that has negative earnings before income, taxes, debt, and amortization (EBITDA) in the previous two years.

Regarding the first condition, a list of 101 companies from Pakistan Stock exchange is used that includes companies suspended over the period 2015-2017. The first 56 companies are selected from the list as the available data of these companies matches our sample period i.e. 2005-2015. However, remaining companies do not have entire data available as they are defaulted in early years (i.e. before 2015) thus no longer recorded by PSX or SBP. For these 56 companies, a dependent variable for the previous four years (' 1 ' stands for financially distressed and ' 0 ' otherwise).

A firm may file bankruptcy for arbitrary protection from their lenders (Haber, 2011). Similarly, failure to the payment of an outstanding annual listing fee is the major reason for companies being suspended by PSX. It is also likely the case that the firm deliberately wants to be delisted or opportunity cost of the annual listing fee is high and so on. To address such problems, the current study uses finance-based definition along with formal bankruptcy as described above. A combination of the aforementioned conditions offers a definition that is employed for the first time for bankruptcy classification in Pakistan.

4 The winsorisation is used to control outliers at the cost of variability of data. For example, a typical $90 \%$ winsorisation set all data below the 5 th percentile to the value of the 5 th percentile. Similarly, it sets all the data above the 95 th percentile.

5 The condition is useful for recent cases only and cannot be used for company defaulted, say, in 2011 because the defaulted company does not have data after 2015. 


\subsubsection{Independent variables}

The variables found common in literature are initially taken for the study. The initial list comprises of 61 variables (see Table 9 in Appendix). The selection of variables from the initial list is guided by the two-step procedure:

Step-1: Test of multicollinearity ${ }^{6}$ and variance inflating factor ${ }^{7}$ (VIF)

The study has estimated correlation and tested whether the correlation between the two variables is different from zero. A variable among the correlated variables is dropped based on corresponding VIF.

Step-2: Step-wise logistic regression model

The stepwise selection procedures are widely used to identify the covariates to be included in the model. From the list of 61 variables, 18 variables qualified after passing through the two-step procedure. The list of the final variables is presented in Table 1.

It is expected for market capitalization to total debt ratio to be inversely related to the PDs. Firms with sufficient liquidity positions also impede bankruptcy so the liquidity ratios are likely to be negatively correlated with PDs. Similarly; profitability, efficiency, and activity ratios are also anticipated to be inversely associated with PDs. However, firms with highly leveraged balance sheets are more likely to have defaulted, therefore, both long-term and short-term debt ratios are predicted to be linked directly with PDs.

Moreover, domestic economic circumstances are also crucial in magnifying or contracting risk exposures. Higher GDP growth rate allows businesses to expand thus mitigating risks. Other macroeconomic variables depend upon the nature of the business. For instance, an increase in the exchange rate may jeopardize the survival of the net importer firm while pacifying the financial conditions of the net exporter company. Which effect dominates? It can be found empirically.

Figure 1 depicts the frequency of bankruptcy (classified on the basis of two definitions above i.e. those which fulfills at least one of the criteria stated above) against years included in the sample.

6 Multicollinearity is the state of intercorrelations among the predictors. It refers that the predictors (found correlated) are explaining similar variations in dependent variables.

7 Variance Inflating Factor; $V I F_{i}=\frac{1}{1-R_{i}^{2}}$, where $R i^{2}$ is the coefficient of determination when ith independent variable is regressed over others. 
Table 1: List of Independent Variables

\begin{tabular}{|c|c|c|}
\hline Type & Variables & Symbol \\
\hline \multicolumn{3}{|c|}{ Market Variables } \\
\hline Market & Market Capitalization to Total Debt & M5 \\
\hline \multicolumn{3}{|c|}{ Financial Ratios } \\
\hline Liquidity & Quick ratio & $\mathrm{A} 2$ \\
\hline Liquidity & Cash Ratio & A3 \\
\hline Liquidity & Current to Total Asset Ratio & A9 \\
\hline Liquidity & Quick to Total Asset Ratio & A10 \\
\hline Liquidity & Cashflow to Short-term Debt Ratio & $\mathrm{A} 12$ \\
\hline Leverage & Short-term Debt to Total Debt Ratio & A19 \\
\hline Leverage & Long-term Debt to Total Asset Ratio & A20 \\
\hline Profitability & Gross Profit Margin & A32 \\
\hline Efficiency & Asset Turnover Ratio & A34 \\
\hline Efficiency & Interest Expense to Debt Ratio & A36 \\
\hline Activity & Net Working Capital to Net Sales Ratio & A38 \\
\hline Activity & Cash to Net Sales Ratio & A43 \\
\hline \multicolumn{3}{|c|}{ Macroeconomic Variables } \\
\hline Macroeconomic & GDP Growth & E2 \\
\hline Macroeconomic & Money Supply (M2) & E3 \\
\hline Macroeconomic & Exchange Rate & E6 \\
\hline Macroeconomic & Forex Reserves & E7 \\
\hline Macroeconomic & Balance of Trade & E9 \\
\hline Macroeconomic & Trade Openness & E10 \\
\hline
\end{tabular}

Cases of Bankruptcies Among Listed Companies

Frequency $\longrightarrow$ Percent

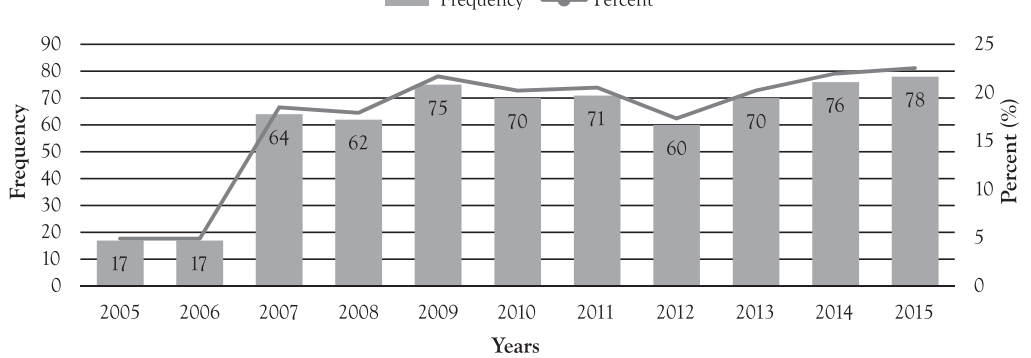

Figure 1: Frequency and Percentage of Bankruptcy Cases Over 2005-2015. 
Table 2: Descriptive Statistics

\begin{tabular}{|c|c|c|c|c|c|c|}
\hline & \multicolumn{2}{|c|}{$\begin{array}{l}\text { Non-bankrupt } \\
\text { firms }\end{array}$} & \multicolumn{2}{|c|}{ Bankrupt firms } & \multicolumn{2}{|c|}{ Overall Sample } \\
\hline & Mean & $\begin{array}{l}\text { Standard } \\
\text { Deviation }\end{array}$ & Mean & $\begin{array}{l}\text { Standard } \\
\text { Deviation }\end{array}$ & Mean & $\begin{array}{l}\text { Standard } \\
\text { Deviation }\end{array}$ \\
\hline Market Cap. to Total Debt & 18.75 & 98.18 & 56.88 & 356.17 & 25.36 & 173.62 \\
\hline Quick Ratio & 1.44 & 11.48 & 12.74 & 77.68 & 3.40 & 34.24 \\
\hline Cash Ratio & 0.42 & 3.02 & 0.25 & 3.19 & 0.39 & 3.05 \\
\hline Current to Total Asset Ratio & 0.48 & 0.21 & 0.34 & 0.26 & 0.46 & 0.23 \\
\hline Quick to Total Asset Ratio & 0.31 & 0.34 & 0.85 & 2.10 & 0.41 & 0.95 \\
\hline Cashflow to Short-term Debt & 0.06 & 0.47 & 0.75 & 22.03 & 0.18 & 9.18 \\
\hline Short-term Debt to Total Debt & 0.75 & 0.20 & 0.67 & 0.30 & 0.74 & 0.23 \\
\hline Long-term Debt to Total Asset & 0.16 & 0.17 & 0.40 & 0.86 & 0.20 & 0.40 \\
\hline Gross Profit Margin & 0.13 & 0.51 & -0.48 & 5.77 & 0.02 & 2.46 \\
\hline Asset Turnover Ratio & 1.22 & 0.81 & 0.57 & 0.75 & 1.10 & 0.84 \\
\hline Interest Expense to Debt & 0.04 & 0.45 & 0.02 & 0.21 & 0.04 & 0.42 \\
\hline Net Working Capital to Net Sales & 0.26 & 14.44 & -6.19 & 65.91 & -0.86 & 30.51 \\
\hline Cash to Net Sales Ratio & 0.05 & 0.26 & 0.16 & 2.14 & 0.07 & 0.92 \\
\hline \multicolumn{7}{|c|}{ Industries dummies } \\
\hline 1. Textile & 0.38 & & 0.60 & & 0.46 & \\
\hline 2. Food & 0.14 & & 0.08 & & 0.13 & \\
\hline $\begin{array}{c}\text { 3. Chemicals, Chemical Products } \\
\text { and Pharmaceuticals }\end{array}$ & 0.10 & & 0.05 & & 0.10 & \\
\hline $\begin{array}{l}\text { 4.Other Non-Metallic Mineral } \\
\text { Products }\end{array}$ & 0.15 & & 0.12 & & 0.14 & \\
\hline 5. Motor Vehicles & 0.06 & & 0.01 & & 0.05 & \\
\hline 6. Fuel \& Energy & 0.07 & & 0.06 & & 0.07 & \\
\hline $\begin{array}{l}\text { 7. Information \& Communica- } \\
\text { tion Services, other services }\end{array}$ & 0.05 & & 0.06 & & 0.05 & \\
\hline 8. Paper, Paperboard \& Products & 0.03 & & 0.60 & & 0.46 & \\
\hline $\begin{array}{l}\text { 9. Electrical Machinery \& Appa- } \\
\text { ratus }\end{array}$ & 0.02 & & 0.08 & & 0.13 & \\
\hline
\end{tabular}

\subsection{Methodology ${ }^{8}$}

In this paper, we employ three empirical modelling approaches in such a way 
that each model captures distinct aspects. First, dynamic panel probit of Wooldridge (2005) is selected as it accommodates the dynamic nature of the problem and provides useful interpretation by average partial effect estimates. To the best of our knowledge, no previous study has employed the dynamic panel probit model for predicting bankruptcy, therefore, it serves as a contribution of the current study.

Other frequently used models in the literature are employed here i.e. hybrid-ANN model and Merton's model. Former is well-known for greater predictability while later is renowned for its roots in option pricing theory.

\subsubsection{Dynamic panel model}

The presence of the lagged dependent variable leads to the violation of strict exogeneity of the regressor resulting endogeneity bias that leads to inconsistent estimates (Ullah, Akhtar \& Zaefarian, 2018). Arellano and Bond (1991) provide an estimation procedure for the dynamic panel model. Wooldridge (2005), however, identified the approach to model dynamic panel for the limited dependent variable by modeling the distribution of the unobserved effect conditional on the initial value and any exogenous explanatory variables. The advantage of the approach is that strictly exogenous variables along with lagged dependent variable can be easily incorporated as well as it mitigates endogeneity bias. Wooldridge (2005) has extended the Chamberlain's (1980) correlated random-effects approach by specifying auxiliary density as $f\left(c_{i} \mid x_{i t}, Y_{1 i}\right)$. The rationale to include dynamic version is the intuition that firms that get bankrupt, bearing hard times in the preceding years, therefore, the autoregressive scheme is reasonable. Literature also evident studies that emphasize the dynamic nature of the bankruptcy (Campbell et al., 2008; Shumway, 2001). The current study uses Wooldridge's (2005) approach for estimating parameters presented in equation (1) and (2). The dynamic model for the bankruptcy prediction employed in this study takes the following form:

$$
\begin{aligned}
& Y_{i t}^{*}=\beta Y_{i(t-1)}^{*}+\gamma^{\prime} X_{i t}+\varepsilon_{i t} \\
& Y_{i 0}^{*}=\gamma^{\prime} X_{i 0}+\varepsilon_{i 0} \\
& \varepsilon_{i t}=c_{i}+u_{i t}
\end{aligned}
$$

where $Y_{i 0}^{*}$ are the initial values; $Y_{i t}=1\left(Y_{i t}^{*}>0\right)$ and $Y_{i} 0=1\left(\left(Y_{i 0}^{*}>0\right)\right.$,

Wooldridge (2005) suggests modeling the distribution of $\mathrm{Y}_{\mathrm{it}}{ }^{*}$ given $\mathrm{Y}_{\mathrm{i} 0}{ }^{*}$ and to use conditional maximum likelihood (ML) estimator. It assumes:

$$
P\left(Y_{i t} \mid X_{t}, c_{i}, Y_{i t}\right)=\phi\left(\beta Y_{i(t-1)}^{*}+\gamma^{\prime} X_{i t} \rho_{o}+\rho_{1} Y_{i 0}+\rho_{2} \bar{X}_{i}+a_{i}\right)
$$




$$
c_{i}=\rho_{o}+\rho_{1} Y_{i 0}+\rho_{2} \bar{X}_{i}+a_{i}
$$

where $\phi($.$) is the normal cumulative distribution function (cdf), X_{\mathrm{it}}$, is a vector of explanatory variables including financial ratios, macroeconomic and market-based variables respectively; $a_{i}$ is unobserved individual-effects and is assumed as $a_{i} \mid \bar{X}_{i}, Y_{1 i}$ i.i.d. $\mathrm{N}\left(0, \sigma_{\mathrm{a}}^{2}\right)$. are the within means vector of the time-varying explanatory variables i.e. $\bar{X}_{i}=\frac{1}{T} \sum_{t=1}^{T} X_{i t}$

\subsubsection{Hybrid artificial neural network (ANN)}

Research studies on utilizing neural network models for predicting financial distress started in the 1990s $\mathrm{s}^{9}$ and growing continuously. Zhang, Hu, Patuwo, and Indro (1999) show that the neural network outperforms the other prediction models such as a logistic regression model. Jo and Han (1996) use hybrid ANN by combining financial ratios identified by MDA or decision tree and then use them as the input layer neurons in ANN. Their study found that unsupervised MDA- assisted ANN outperforms the others. This study in this respect is analogous to that of Lee et al. (1996) in a way that we identify variables from the statistical model and use them as inputs (neurons) in ANN.

The current study provides a two-way hybridization of ANN. Using three types of variables (i.e. financial ratios, market-based, and macroeconomic variables) simultaneously serves one way (Tinoco et al., 2015). Among these variables, significant variables found in a dynamic panel model is used as input variables for ANN is the second way of hybridization. The hybrid version of ANN appears attractive in addressing much-debated vanishing gradient problem associated with sigmoid function as gradient become increasingly small while dealing with a large number of neurons.

We calculate a weighted sum of the inputs by means of integration function, represented in equation (4), at each hidden node. Each node then uses a sigmoid transfer function to generate an output between 0 and 1 , depicted in equation (5). Finally, the sigmoid function bridges the hidden layer and the output layer.

$$
\begin{array}{ll}
\text { Integration function: } & f_{1}=f_{1}(x)=w_{0}+\sum_{i=1}^{k} w_{i} x_{i} \\
\text { Sigmoid function: } & f_{2}=f_{2}\left(f_{1}(x)\right)=\frac{1}{1+e^{-f_{1}(x)}} \\
\text { Output: } & \hat{Y}=f_{2}\left(f_{1}(x)\right)
\end{array}
$$

where $f_{1}($.$) is the integration function which is simply the weighted sum of inputs.$ $f_{2}($.$) is the activation function which is nondecreasing, nonlinear, and differentiable.$

9 See Hill, Marquez, Connor, and Remus (1994) for the survey of Artificial Neural Network models and its applications. 
The cross-entropy (CE) error term is used rather than a sum of squared residual (SSE) as CE is assumed to be better than SSE for binary classification problems. An error-function $E$,

$$
E=-\sum_{n=1}^{N}\left[Y_{n} \log \left(\hat{Y}_{n}\right)+\left(1-Y_{n}\right) \log \left(1-\hat{Y}_{n}\right)\right]
$$

measures the difference between predicted and actual output, where $n=1,2, \ldots$, $\mathrm{N}$ are the observations corresponding to input-output pairs.

Initial weights, employed in equation (3), are drawn from the standard normal distribution and these weights are then iteratively adjusted by using the backpropagation algorithm. Mathematically,

$$
w_{k}^{(t+1)}=w_{k}^{(t)}-\eta_{k}^{(t)} \cdot \frac{\partial E^{(t)}}{\partial w_{k}^{(t)}}
$$

where $t$ indexes the iteration steps for $k$-th weight and ' $\eta$ ' is the learning rate and will be increased if the corresponding partial derivative keeps its sign. The partial derivative (gradient) i.e. $\frac{\partial E^{(t)}}{\partial w_{k}^{(t)}}$ is a sensitivity factor, determining the direction of search in weight space for the weight $\mathrm{w}_{\mathrm{k}}$. This gradient can be expressed as,

$$
\frac{\partial E^{(t)}}{\partial w_{k}^{(t)}}=\frac{\partial E^{(t)}}{\partial f_{2}^{(t)}} \frac{\partial f_{2}^{(t)}}{\partial f_{1}^{(t)}} \frac{\partial f_{1}^{(t)}}{\partial w_{k}^{(t)}}
$$

The last factor of the right-hand side of equation (8),

$$
\frac{\partial f_{1}^{(t)}}{\partial w_{k}^{(t)}}=\frac{\partial}{\partial w_{k}^{(t)}}\left(w_{0}+\sum_{i=1}^{k} w_{i} x_{i}\right)=x_{i}
$$

The derivative of the output neuron with respect to its input is simply the partial derivative of the sigmoid function, it implies

$$
\frac{\partial f_{2}^{(t)}}{\partial f_{1}^{(t)}}=f_{2}(.)\left\{1-f_{2}(.)\right\}
$$

Finally, the first factor of the right-hand side of equation (8):

$$
\frac{\partial E^{(t)}}{\partial f_{2}^{(t)}}=\frac{\partial E^{(t)}}{\partial \hat{Y}^{(t)}}=Y_{n}\left(\hat{Y}_{n}-1\right)+\left(1-Y_{n}\right)\left(\hat{Y}_{n}\right)
$$

\subsubsection{Merton's model}

The model belongs to the class of structural models. These types of models have been used extensively by credit rating agencies. These models rely on insights from option pricing theory which states that holding equity is economically comparable to a European call option on the company's asset with the strike price equivalent to the value of debt. According to Merton's model, the firm is treated as defaulted if its market value is less than its debt. The market value of the equity $\left(\mathrm{S}_{\mathrm{o}}\right)$ is calculated by the Black and Scholes (1973) formula for call options. 
$S_{o}=V_{o} \phi\left(d_{1}\right)-B e^{-r T} \phi\left(d_{2}\right)$

' $\mathrm{S}_{\mathrm{o}}$ ' is the market capitalization

' $V_{o}$ ' is the firm's assets value (total assets)

'B' is the book value of the firm's liabilities (Long-term Liabilities + Current Liabilities)

' $\mathrm{r}$ ' is the risk-free interest rate

' $T$ ' is the time period for debt maturity

where,

$d_{1}=\frac{\log \left(V_{o} / B\right)+\left(r+\sigma_{v}^{2} / 2\right) T}{\sigma_{v} \sqrt{T}}$

and, $\quad d_{2}=d_{1}-\sigma_{v} \sqrt{T}$

where $\sigma_{v}$ is the volatility of the asset and $\phi($.$) is the cumulative distribution func-$ tion of a Standard Gaussian Distribution. Therefore, the probability of default can be calculated as,

$$
P\left(V_{T} \leq B\right)=\phi\left(\frac{\log \left(B / V_{o}\right)-\left(r-\sigma_{v}^{2} / 2\right) T}{\sigma_{v} \sqrt{T}}\right)=\phi\left(-d_{2}\right)
$$

since $\mathrm{V}_{\mathrm{o}}$ and $\sigma_{v}$ are not directly observable in any frictionless market, we can find an iterative solution of these quantities with the help of equation (12) together with equation (16).

$$
S_{o}=\frac{\sigma_{v}}{\sigma_{s}} \phi\left(d_{1}\right) V_{o}
$$

where $\sigma_{s}$ is the instantaneous volatility. It can be calculated by equity returns for each year. Equation (9) provides estimates of the probability of default.

\section{Empirical Results}

\subsection{Results of the dynamic panel model ${ }^{10}$}

The results for the dynamic random effect panel probit model are presented in Table 3 which reports the coefficients and average partial effect (APE) of each variable. The coefficients in a non-linear model can only indicate the direction of a relationship whereas APEs reflect the magnitude. The model attained $92.3 \%$ of

10 It is to be noted that financial ratios are in absolute form while macroeconomic variables are in natural logarithm form (except for GDP growth rate). Coefficients are, therefore, interpreted accordingly. 
the predictive accuracy for in-sample forecasts (Out-of-sample forecast is discussed in Section-5.2). The highly significant coefficient on the lagged firm's status suggests a substantial degree of positive state dependence. The estimate of (i.e. 0.202) indicates that $20 \%$ of the total variation is due to individual variation.

Among other explanatory variables, none of the stock market-based variables is found significant. It suggests prevailing market inefficiency as market variables do not contain information regarding the financial distress of the firms and are unable to explain variations in the probability of default. Alternatively, equity market movements are not aligned with the financial conditions of the firm and the stock prices of these firms (with high PD) are not reflecting the true economic reality. Thus, the failure of market variables in explaining the probability of default brings some evidence of default risk anomaly and mispricing of stocks of financially distressed firms. An active investor can earn an abnormal profit by utilizing market inefficiencies. For instance, an investment strategy while exploiting default risk anomaly is to short-sell the stocks of these firms and close the position once firms eventually get bankrupt.

The liquidity (quick ratio, cash ratio, current to total asset, quick to total asset, cash flow to short-term debt), profitability (gross profit margin), efficiency (asset turnover, interest expense to debt), and activity (net working capital to sales) ratios are found significant among financial ratios in explaining the probability of defaults. Except for quick ratio and quick to total asset ratio, coefficients of all other ratios are consistent with the economic rationale. The average increase in the probability of default with one unit increase in the quick ratio is 0.001 while the increase in cash ratio decreases the probability of default by 0.021 . Components of both quick and cash ratios are identical except the fact that the quick ratio includes account receivables additionally. Account receivables are generated when a company makes sales on credit which raises counterparty default risk. It implies that the debtor's credit risk is associated with the company's credit risk. Similarly, current to total asset and quick to total asset affects the probability of default in opposite directions. Former decrease the probability, on average, by 0.084 while later increase the probability by 0.04 . Analogous interpretation can be made for a positive relationship between quick to total assets and the probability of default. Impact of the liquidity ratios employed in this study akin to that of Deakin (1972). Cashflow to short-term debt (or short-term debt coverage ratio) raises the probability of default by 0.011 units, ceteris paribus. A potential explanation is that the companies are devoting most of their operating cash flow in short-term debt servicing thus higher the ratio implies a higher probability of default. Similarly, the contribution of the asset turnover ratio is similar to that of Altman (1968), and Altman, Haldeman, and Narayanan (1977) i.e. the depressing probability of default. Moreover; gross-profit margin, interest expense to debt ratio, net working capital to 
sales, and cash to net sales are adversely affecting the probability of default and are in line with the economic theory.

Additionally, any increase in money supply, exchange rate, and forex reserves are crucial in enhancing PDs. Money supply, measured by M2, is the sum of currency in circulation, demand deposits by banks, and other deposits. An increase in M2 surges the inflation in the economy which increases the cost of doing business. It is estimated that if the money supply increase by one percent would raise the likelihood of default by 0.04 percentage points, keeping all other variables constant. Moreover, the exchange rate also affects the financial positions of the firms seeking profit from exports or using imported raw materials. Weaker currency expands the cost of raw materials to be imported which complements the profitability of the companies. The coefficient on exchange rate implies that a percent rise in the exchange rate or a domestic currency weakened by one percent will, on average, increase the probability of default by 0.3 percentage points. In addition to this, an increase in forex reserves also smoothens the way towards bankruptcy. In the context of Pakistan, a potential explanation of the positive and statistically significant relationship between forex reserves and probability of default is that forex reserves have mostly increased by foreign borrowing rather than improvements in the balance of trade thus imposing additional risk. So, a percent increase in forex reserves will increase the probability of default by 0.05 percentage points, ceteris paribus. Similarly, a percent increase in the trade balance would reduce the likelihood of being default by 0.31 percentage points.

Table 3 also depicts the corresponding results of eight dummy variables to capture idiosyncratic industry effects. It is evident that except for the food industry, other industries possess significantly different default risk characteristics than the textile industry (benchmark category). Fuel industry contributes the highest probability of default ( 0.025 higher than textiles) among all while paper, paperboard $\&$ products industry accounts the lowest individual probability of default (i.e. 0.017 lower than the textile). The potential reason for high default risk in the fuel industry is exposure to both international and domestic economic conditions. International oil prices are relatively volatile and the government generally regulates these prices on the domestic premises. Moreover, the fuel industry is more heavily taxed in the country's jurisdiction than any of the other industries employed in this study. In contrast to this, the paper industry is less likely to get defaulted as most of the inputs of the industry are domestically available and demand (both domestic and foreign) is consistently increasing which remains the industry profitable. Chava and Jarrow (2004) demonstrate the significance of industry effects in assessing the probability of defaults. Furthermore, a dummy is also capturing business cycle variations. It is found that firms during a recession display a higher propensity to get defaulted than during expansion. It is 
pertinent to note that none of the equity market variables contributes statistically in predicting bankruptcy.

Table 3: Regression Results of Dynamic Panel Probit

\begin{tabular}{|c|c|c|}
\hline Explanatory variables & Coefficients & Average Partial Effects (APEs) \\
\hline Constant & $-19.641(4.153)$ * & - \\
\hline Financially_Distressed0 & $0.363(0.171)^{* *}$ & - \\
\hline Financially_Distressedt-1 & $1.982(0.117)^{*}$ & $0.214(0.214) *$ \\
\hline Market Capitalization to Total Debt & $-0.002(0.007)$ & $0.000(0.001)$ \\
\hline Quick Ratio & $0.005(0.002)^{* *}$ & $0.001(0.000) * *$ \\
\hline Cash Ratio & $-0.193(0.069) *$ & $-0.021(0.008) *$ \\
\hline Current Asset/Total Asset Ratio & $-0.776(0.417)^{* * *}$ & $-0.084(0.047)^{* * *}$ \\
\hline Quick Asset/Total Asset Ratio & $0.370(0.150)^{* *}$ & $0.040(0.018)^{* *}$ \\
\hline Cash flow to short-term Debt Ratio & $0.102(0.012) *$ & $0.011(0.001) *$ \\
\hline Short-term Debt to Total Debt Ratio & $0.473(0.297)$ & $0.051(0.031)$ \\
\hline Long term Debt to Total Asset ratio & $0.503(0.483)$ & $0.054(0.051)$ \\
\hline Gross Profit Margin & $-0.614(0.169) *$ & $-0.066(0.020) *$ \\
\hline Asset Turnover Ratio & $-0.430(0.199)^{* *}$ & $-0.046(0.023) * *$ \\
\hline Interest Expense to Debt Ratio & $-8.679(1.902) *$ & $-0.938(0.181) *$ \\
\hline Net Working Capital to Net Sales & $-0.015(0.006) *$ & $-0.002(0.001) *$ \\
\hline Cash to Net Sales Ratio & $-1.339(0.409) *$ & $-0.145(0.048) *$ \\
\hline GDP Growth Rate & $0.481(0.199)^{* *}$ & $0.052(0.022)^{* *}$ \\
\hline$\Delta \log$ (Money Supply, M2) & $0.424(0.213)^{* *}$ & $0.046(0.023)^{* *}$ \\
\hline$\Delta \log$ (Exchange rate) & $3.497(1.061) *$ & $0.378(0.123)^{*}$ \\
\hline$\Delta \log ($ Forex Reserve) & $0.492(0.097) *$ & $0.053(0.011) *$ \\
\hline$\Delta \log$ (Balance of trade) & $-2.843(0.900) *$ & $-0.307(0.101) *$ \\
\hline$\Delta \log$ (Openness) & $-0.703(5.670)$ & $-0.076(0.613)$ \\
\hline \multicolumn{3}{|l|}{ Industry dummy: } \\
\hline Food & $-0.033(0.030)$ & $-0.004(0.003)$ \\
\hline $\begin{array}{c}\text { Chemicals, Chemical Products and } \\
\text { Pharmaceuticals }\end{array}$ & $-0.185(0.036) *$ & $-0.020(0.004) *$ \\
\hline $\begin{array}{l}\text { Other Non-Metallic Mineral Prod- } \\
\text { ucts }\end{array}$ & $-0.154(0.024) *$ & $-0.016(0.002) *$ \\
\hline Motor Vehicles & $-0.479(0.0719) *$ & $-0.046(0.007)^{*}$ \\
\hline Fuel \& Energy & $0.204(0.094) * *$ & $0.025(0.011)^{* *}$ \\
\hline
\end{tabular}




\begin{tabular}{|c|c|c|}
\hline $\begin{array}{c}\text { Information \& Communication } \\
\text { Services, others }\end{array}$ & $0.169(0.046)^{*}$ & $0.020(0.006)^{*}$ \\
\hline Paper, Paperboard and Products & $-0.821(0.124)^{*}$ & $-0.072(0.009)^{*}$ \\
\hline Electrical Machinery and Apparatus & $-0.154(0.067)^{* *}$ & $-0.017(0.006)^{*}$ \\
\hline Business cycle dummy: & & \\
\hline Recession & $1.059(0.498)^{* *}$ & $0.111(0.05)^{*}$ \\
\hline & & \\
\hline$\hat{\sigma}_{a}^{2}$ & 0.202 & \\
\hline Log-likelihood value & -3.196 & \\
\hline
\end{tabular}

Note: ${ }^{* * *}$ Coefficient is significant at $10 \%$ level of significance, ${ }^{* *}$ significant at $5 \%$ level of significance, * significant at $1 \%$ level of significance. Standard errors are shown in parenthesis.

The classification results, presented in Table 4, compares the actual with the predicted outcome. It is found that the model correctly classified $96.5 \%$ non-bankrupt firms while $73.8 \%$ of the bankrupt firms. The low rate of true bankruptcy than non-bankruptcy classification is because of the disproportionate sample size of bankrupt versus non-bankrupt firms ${ }^{11}$. The false classification arises two types of errors ${ }^{12}$. The dynamic panel probit model produced 26.1 percent Type 1 and 3.4 percent Type 2 errors. The results are based on the in-sample forecast.

Table 4: Classification Results - Dynamic Panel Probit Model

\begin{tabular}{|c|c|c|c|c|}
\hline \multirow{2}{*}{ Original Count } & \multicolumn{4}{|c|}{ Predicted Group Membership } \\
\cline { 2 - 5 } & $\mathrm{N}=3,460$ & Non-bankrupt & Bankrupt & Total \\
\cline { 2 - 5 } & Non-bankrupt & 2,719 & 98 & 2,817 \\
\cline { 2 - 5 } & Bankrupt & 168 & 475 & 643 \\
\hline \multirow{2}{*}{ Percentage } & Non-bankrupt & 96.5 & 3.4 & 100.0 \\
\cline { 2 - 5 } & Bankrupt & 26.1 & 73.8 & 100.0 \\
\hline
\end{tabular}

\subsection{Results of the hybrid artificial neural network}

The variables found significant in the dynamic panel fixed effect model is used to build an architecture of ANN as otherwise large networks heighten the risk of overfitting (Srivastava, Hinton, Krizhevsky, Sutskever, \& Salakhutdinov, 2014). Therefore, only macroeconomic and financial variables remained in the model whereas none of the stock market variables found significant in predicting bankruptcy. Moreover, the study relies on the interpretation based on APE estimates of dynamic probit model

11 Only $17 \%$ of the total observations corresponds to bankrupt firms.

12 The prediction of bankrupt as non-bankrupt is Type 1 error and forecasting of non-bankrupt as bankrupt is known as Type 2 error in the context of the bankruptcy classification problem. 


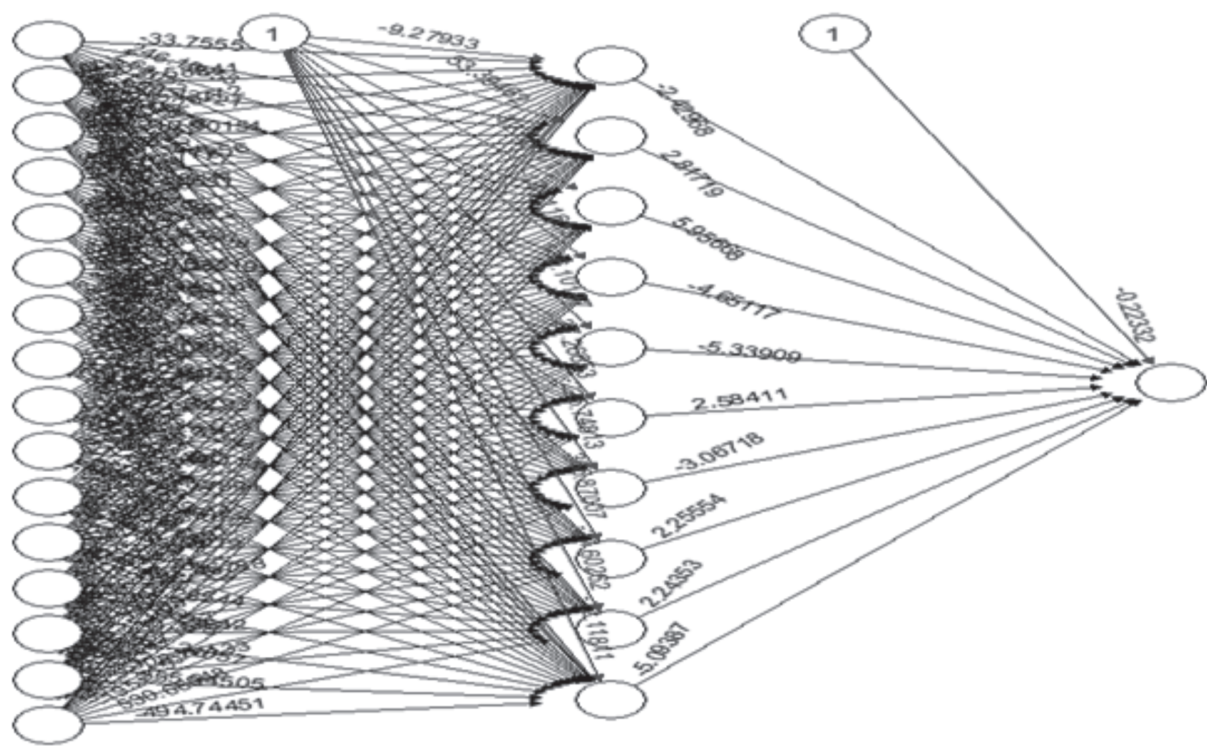

Figure 2: Architecture for Hybrid Artificial Neural Network

as hybrid ANN has difficulty in explaining estimated coefficients (Min \& Lee, 2005).

Figure 2 represents the optimal network for the dataset employed for the study. Leftmost orbits are representing explanatory variables while middle orbits are the hidden neurons and finally, a rightmost singular orbit is representing the outcome variable. The numerals over each synapse (arrow connecting two orbits) are the weights derived by minimizing cross-entropy error. It is found that the optimal model consists of a single hidden layer with 11 hidden neurons.

Table 5 presents the classification accuracy corresponding to the hybrid ANN model. It is evident that the model attains 97.9 percent accuracy in classifying non-bankrupt companies, however, it gains 87.7 percent accuracy in classifying bankrupt companies. Alternatively, type 1 and type 2 error for hybrid-ANN are 12.2 percent 2.3 percent respectively.

Table 5: Classification Results - Hybrid-ANN Model

\begin{tabular}{|c|c|c|c|c|}
\hline \multirow{2}{*}{ Original Count } & \multicolumn{4}{|c|}{ Predicted Group Membership } \\
\cline { 2 - 5 } & $\mathrm{N}=3,460$ & Non-bankrupt & Bankrupt & Total \\
\cline { 2 - 5 } & Non-bankrupt & 2,759 & 58 & 2,817 \\
\hline \multirow{2}{*}{ Percentage } & Bankrupt & 79 & 564 & 643 \\
\cline { 2 - 5 } & Non-bankrupt & 97.7 & 2.0 & 100.0 \\
\cline { 2 - 5 } & Bankrupt & 12.2 & 87.7 & 100.0 \\
\hline
\end{tabular}




\subsection{Results of Merton's model}

The probability of default is obtained from equation (10). The model gets an overall 73 percent accuracy for the in-sample forecast. The corresponding classification results of Merton's model are presented in Table 6. It is found that the model achieved $31.3 \%$ accuracy in classifying bankrupt firms while correctly classified 86.8 percent of non-. Relatively weak predictive ability and statistically insignificant coefficient of market variables bring some evidence of market inefficiency. It further suggests that stock market prices are default risk is not correctly priced. Merton's model produced 68.6 percent Type 1 and 13.1 percent Type 2 errors. It implies that primary parameters of Merton's model i.e. book value to total liabilities, the market value of the firm's asset, and the standard deviation of firm value do not contain much information pertaining to financial distress.

Table 6: Classification Results - Merton's Model

\begin{tabular}{|c|c|c|c|c|}
\hline \multirow{2}{*}{} & \multicolumn{4}{|c|}{ Predicted Group Membership } \\
\cline { 2 - 5 } & $\mathrm{N}=3806$ & Non-bankrupt & Bankrupt & Total \\
\hline \multirow{2}{*}{ Original Count } & Non-bankrupt & 2,543 & 385 & 2,928 \\
\cline { 2 - 5 } & Bankrupt & 603 & 275 & 878 \\
\hline \multirow{2}{*}{ Percentage } & Non-bankrupt & 86.8 & 13.1 & 100.0 \\
\cline { 2 - 5 } & Bankrupt & 68.6 & 31.3 & 100.0 \\
\hline
\end{tabular}

\section{Model Diagnostics}

\subsection{Cross-validation analysis}

Cross-validation is the statistical technique that allows comparing the learning methods by dividing the data set into two groups: first is to train the network and remaining is to validate (test) the fit. Zhang et al. (1999) used cross-validation to evaluate the appropriateness of the neural network for bankruptcy prediction.

This study uses $k$-fold cross-validation (where $k=10$ is taken because of its popularity). It implies that the total sample of 3,806 observations is divided into ten equal parts. Each class must appear once in both training and validating stages. The average misclassification rate (MR) is used to summarize the fit. However, PDs from the Merton's model are estimated by using distinct parameters for each firm. Therefore, following Charitou, Lambertides, and Trigeorgis (2008), regress binary dependent variable on PDs (from Merton's model) by means of logistic regression, cross-validation is then applied to this setting. 
The results of the 10-fold cross-validation test are presented in Table 7. Moreover, an in-sample forecast is also summarized so that comparison can be made. It is found that hybrid-ANN outperforms other models regarding both in-sample and out-ofsample forecast estimates.

Table 7: Models Comparison: In-Sample and Out-of-Sample Forecasting Accuracy

\begin{tabular}{|c|c|c|}
\hline Models & In-sample forecast accuracy & Out-of-sample accuracy \\
\hline Dynamic Panel Model & $92.3 \%$ & $91 \%$ \\
\hline Hybrid-ANN Model & $96 \%$ & $93.1 \%$ \\
\hline Merton's Model & $73.6 \%$ & $74.04 \%$ \\
\hline
\end{tabular}

\subsection{Receiver operating characteristics (ROC)}

Receiver Operating Characteristics (ROC), for a two-class problem, allows visualizing trade-off between the rate at which model can accurately recognize positive cases vs the rate at which it mistakenly identifies negative.

The probability of defaults is derived from each model and use to classify firms into two classes (bankrupt versus non-bankrupt). The ROC curve is plotted by using actual and predicted classifications. The $45^{\circ}$ line (random-guess line) divides the space into two portions. The curve farther from the diagonal represent a better fit as compared to the curve closer to the diagonal.

The area under the ROC curve (AUC) represents the rate of true classification. Figure 3 plots the area under the curve (AUC) of three bankruptcy prediction models employed in this study. Curves $\mathrm{y}_{1}, \mathrm{y}_{2}$, and $\mathrm{y}_{3}$ correspond to predicted values of dynamic probit, hybrid ANN, and Merton's model respectively. The comparison is performed using a non-parametric method to compare the AUC. It is found that the ROC curve of ANN has captured 98.6 percent area - the largest AUC among three models. 


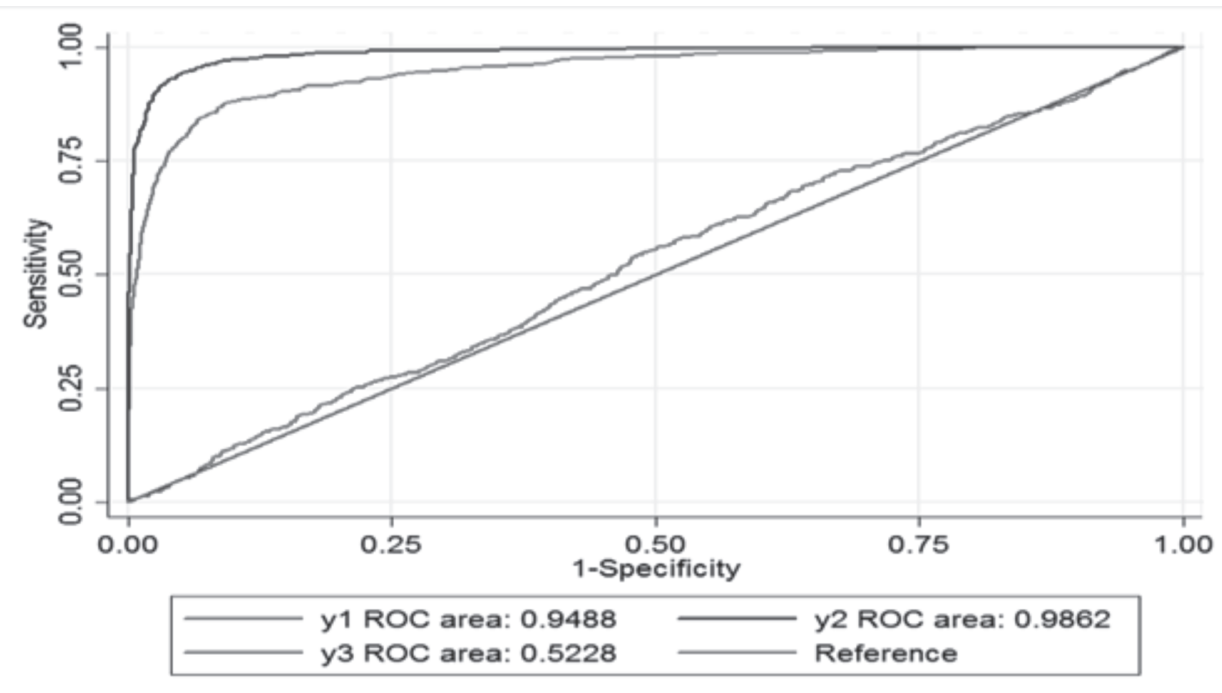

Figure 3: Receiver Operating Characteristic (ROC) curve

\section{Conclusion}

This study compares the predictive accuracy of three models i.e. dynamic panel probit, hybrid ANN, and Merton's model by employing three types of variables (financial ratios, stock-market based variables and macroeconomic indicators) based on the integration of finance-based definition with legal classification for listed non-financial companies in Pakistan. It extends the literature by, first, employing a combined definition for classifying financially distressed firms of Pakistan. Firms, in some cases, file bankruptcy in order to seek temporary protection without being a financially distressed provoking conflict of interest among stakeholders. A combination of finance-based definition with actual bankruptcy classification help mitigate such agency problems and can be used in simplifying formal procedures for tracing and protecting a business from ultimate bankruptcy. Second, the study offers the hybrid-ANN model, by combining dynamic panel probit model and ANN, which attains relatively higher predictive accuracy in terms of both in-sample and out-of-sample forecasts. The estimation of average partial effects in the context of the dynamic panel logit framework fills an important gap in bankruptcy prediction literature by explaining instantaneous changes in the probability of default in response to change in specific covariate while keeping other predictors constant.

It further contributes to the literature by introducing financial ratios, macroeconomic variables, and equity market variables simultaneously for estimating the probability of default. The financial ratios and macroeconomic variables only are 
found significant for classifying cases into two classes. This study further brings some evidence of mispricing of default risk as none of the stock-market based variables are found significant in explaining bankruptcy. It implies that the stock prices are not reflecting the true economic reality of the firms and raise concerns over stock market efficiency.

Given the dynamic nature of the characteristics of bankrupt/financially distressed firms over time, it is imperative for practitioners, regulators and academicians to test and enhance the bankruptcy prediction models. Therefore, research can further be enhanced by employing more sophisticated data science approaches like support vector machines, genetic programming and others. Similarly, other hybrid versions can also be tested. Moreover, the current study only includes the non-financial sector of Pakistan whereas the predictability of these models can also be tested in the context of the financial sector of Pakistan.

\section{Implications of the study}

The study brings useful implications for various stakeholders. Regulators can stipulate comprehensive bankruptcy law for better protection of businesses and can identify whether liquidation or reorganization suits best for the firms' financial condition by viewing shortlisted significant predictors in the event of bankruptcy. Similarly, financial institutions and creditors could get better insights into the financial performance of the firms before making lending decisions. Probability of default estimates are also useful for credit rating agencies and market participants base their parameter estimates on results reported in rating agency default studies. Testing default risk in asset pricing also requires proxy of default risk, therefore, accuracy in these estimates provide better insights. In sum, measurement of the probability of default is often considered as the first step in credit risk modelling.

\section{References}

Agarwal, V., \& Taffler, R. (2008). Does financial distress risk drive the momentum anomaly? Financial Management, 37(3), 461-484.

Alaka, H. A., Oyedele, L. O., Owolabi, H. A., Kumar, V., Ajayi, S. O., Akinade, O. O., \& Bilal, M. (2018). Systematic review of bankruptcy prediction models: Towards a framework for tool selection. Expert Systems with Applications, 94, 164-184.

Altman, E. I. (1968). Financial ratios, discriminant analysis and the prediction of corporate bankruptcy. The Journal of Finance, 23(4), 589-609.

Altman E. I., Haldeman, R. G., \& Narayanan, P. (1977). ZETA analysis, a new model to identify bankruptcy risk of corporations. Journal of Banking and Finance, 1(1), 29-54. 
Altman, E. I., \& Hotchkiss, E. (2006). Corporate financial distress and bankruptcy: Predict and avoid bankruptcy, analyze and invest in distressed debt (3rd ed.). Hoboken, NJ: John Wiley \& Sons.

Altman, E. I., Marco, G., \& Varetto, F. (1994). Corporate distress diagnosis: Comparisons using linear discriminant analysis and neural networks (the Italian experience). Journal of Banking and Finance, 18(3), 505-529.

Altman, E. I., \& Rijken, H. A. (2011). Toward a bottomlup approach to assessing sovereign default risk. Journal of Applied Corporate Finance, 23(1), 20-31.

Arellano, M., \& Bond, S. (1991). Some tests of specification for panel data: Monte Carlo evidence and an application to employment equations. The Review of Economic Studies, 58(2), 277-297.

Ashraf, S., Félix, E. G. S., \& Serrasqueiro, Z. (2019). Do traditional financial distress prediction models predict the early warning signs of financial distress? Journal of Risk and Financial Management, 12(2), $55-71$.

Bauer, J. (2012). Bankruptcy risk prediction and pricing: Unravelling the negative distress risk premium (Doctoral dissertation, Cranfield University, UK). Retrieved from: http://dspace.lib.cranfield.ac.uk/ handle/1826/7313.

Beaver, W. H. (1966). Financial ratios as predictors of failure. Journal of Accounting Research, 4, 71-111. doi: $10.2307 / 2490171$

Beaver, W. H., Cascino, S., Correia, M., \& McNichols, M. F. (2019). Group affiliation and default prediction. Management Science, 68(8), 3559-3584. http://dx.doi.org/10.2139/ssrn.2850458

Bharath, S. T., \& Shumway, T. (2008). Forecasting default with the Merton distance to default model. The Review of Financial Studies, 21(3), 1339-1369.

Black, F., \& Scholes, M. (1973). The pricing of options and corporate liabilities. Journal of Political Economy, 81(3), 637-654.

Campbell, J. Y., Hilscher, J., \& Szilagyi, J. (2008). In search of distress risk. The Journal of Finance, 63(6), 2899-2939.

Chamberlain, G. (1980). Analysis of covariance with qualitative data. Review of Economic Studies, 47(1), 225-238.

Charitou, A., Lambertides, N., \& Trigeorgis, L. (2008). Bankruptcy prediction and structural credit risk models. In S. Jones \& D. A. Hensher (Eds.), Advances in Credit Risk Modelling and Corporate Bankruptcy Prediction. (pp. 154-174). New York, NY: Cambridge University Press.

Chava, S., \& Jarrow, R. A. (2004). Bankruptcy prediction with industry effects. Review of Finance, 8(4), 537-569.

Deakin, E. B. (1972). A discriminant analysis of predictors of business failure. Journal of Accounting Research, 10(1), 167-179. 
Gharghori, P., Chan, H., \& Faff, R. (2007). Are the fama-french factors proxying default risk? Australian Journal of Management, 32(2), 223-249.

Haber, J. R. (2011). Assessing how bankruptcy prediction models are evaluated. Journal of Business $\mathbb{E}$ Economics Research, 3(1), 87-92.

Hasanain, A., \& Shah, S. A. A. (2012). Investigating the proposed changes to Pakistan's corporate bankruptcy code (CREB Working Paper No. 01-12) Retrieved from Centre for Research in Business and Economics website: http://www.creb.org.pk/uploads/

Hill, T., Marquez, L., O'Connor, M., \& Remus, W. (1994). Artificial neural network models for forecasting and decision making. International Journal of Forecasting, 10(1), 5-15.

Jo, H., \& Han, I. (1996). Integration of case-based forecasting, neural network, and discriminant analysis for bankruptcy prediction. Expert Systems with Applications, 11(4), 415-422.

Khan, U. E. (2018). Bankruptcy prediction for financial sector of Pakistan: Evaluation of logit and discriminant analysis approaches. Pakistan Journal of Engineering, Technology $\mathcal{E}$ Science, 6(2), 210-220.

Khemakhem, S., \& Boujelbene, Y. (2018). Predicting credit risk on the basis of financial and non-financial variables and data mining. Review of Accounting and Finance, 17(3), 316-340.

Lee, K. C., Han, I., \& Kwon, Y. (1996). Hybrid neural network models for bankruptcy predictions. Decision Support Systems, 18(1), 63-72.

Luqman, R., Ul Hassan, M., Tabasum, S., Khakwani, M. S., \& Irshad, S. (2018). Probability of financial distress and proposed adoption of corporate governance structures: Evidence from Pakistan. Cogent Business $\mathcal{E}$ Management, 5(1). DOI: 10.1080/23311975.2018.1492869

Mai, F., Tian, S., Lee, C., \& Ma, L. (2019). Deep learning models for bankruptcy prediction using textual disclosures. European Journal of Operational Research, 274(2), 743-758.

Merton, R. C. (1974). On the pricing of corporate debt: The risk structure of interest rates. The Journal of Finance, 29(2), 449-470.

Min, J. H., \& Lee, Y. C. (2005). Bankruptcy prediction using support vector machine with optimal choice of kernel function parameters. Expert systems with applications, 28(4), 603-614.

Ohlson, J. A. (1980). Financial ratios and the probabilistic prediction of bankruptcy. Journal of Accounting Research, 18(1), 109-131.

Pindado, J., Rodrigues, L., \& de la Torre, C. (2008). Estimating financial distress likelihood. Journal of Business Research, 61(9), 995-1003.

Rashid, A., \& Abbas, Q. (2011). Predicting bankruptcy in Pakistan. Theoretical and Applied Economics, 18(9), 103-128.

Securities and Exchange Commission of Pakistan. (2009d). Corporate Rehabilitation Act. Retrieved from: 
http://www.secp.gov.pk/

Shumway, T. (2001). Forecasting bankruptcy more accurately: A simple hazard model. The Journal of Business, 74(1), 101-124.

Srivastava, N., Hinton, G., Krizhevsky, A., Sutskever, I., \& Salakhutdinov, R. (2014). Dropout: A simple way to prevent neural networks from overfitting. The Journal of Machine Learning Research, 15(1), 1929-1958.

Tinoco, M. H., Holmes, P., \& Wilson, N. (2015). Polytomous response financial distress models: The role of accounting, market and macroeconomic variables. International Review of Financial Analysis, $59,276-289$.

Tinoco, M. H., \& Wilson, N. (2013). Financial distress and bankruptcy prediction among listed companies using accounting, market and macroeconomic variables. International Review of Financial Analysis, 30, 394-419.

Ullah, S., Akhtar, P., \& Zaefarian, G. (2018). Dealing with endogeneity bias: The generalized method of moments (GMM) for panel data. Industrial Marketing Management, 71, 69-78. https://doi. org $/ 10.1016 /$ j.indmarman.2017.11.010

Vassalou, M., \& Xing, Y. (2004). Default risk in equity returns. The Journal of Finance, 59(2), 831-868.

Wooldridge, J. M. (2005). Simple solutions to the initial conditions problem in dynamic, nonlinear panel data models with unobserved heterogeneity. Journal of Applied Econometrics, 20(1), 39-54.

Zhang, G., Hu, M. Y., Patuwo, B. E., \& Indro, D. C. (1999). Artificial neural networks in bankruptcy prediction: General framework and cross-validation analysis. European Journal of Operational Research, 116(1), 16-32. 


\section{Appendix}

Table 8: Review of Methodologies for Selected Bankruptcy Prediction Studies

\begin{tabular}{|c|c|c|c|c|}
\hline Author & Variables & Technique & Data & Conclusion \\
\hline Altman (1968) & Financial Ratios & $\begin{array}{l}\text { Multiple Discrim- } \\
\text { inant Analysis }\end{array}$ & $\begin{array}{c}78 \text { firms over } \\
1946-1965 .\end{array}$ & $\begin{array}{l}\text { The model } \\
\text { attained } 94 \% \\
\text { accuracy in terms } \\
\text { of classification. } \\
\text { The model } \\
\text { develops well } \\
\text { known Z-score (or } \\
\text { Altman's Z-score). }\end{array}$ \\
\hline Ohlson (1980) & Financial Ratios & $\begin{array}{c}\text { Conditional logit } \\
\text { model }\end{array}$ & $\begin{array}{c}105 \text { bankrupt } \\
\text { firms and } 2058 \\
\text { non-bankrupt } \\
\text { firms for } 1970 \text { - } \\
1976\end{array}$ & $\begin{array}{l}\text { The binary logit } \\
\text { model endorsed } \\
\text { the predictive } \\
\text { abilities of } \\
\text { accounting } \\
\text { ratios. However, } \\
\text { it points out the } \\
\text { limitation that } \\
\text { market variables } \\
\text { also contain some } \\
\text { information. }\end{array}$ \\
\hline $\begin{array}{l}\text { Altman et al. } \\
\text { (1994) }\end{array}$ & Financial Ratios & $\begin{array}{l}\text { Artificial Neural } \\
\text { Network, Linear } \\
\text { Discriminant } \\
\text { Analysis, logistic } \\
\text { regression }\end{array}$ & $\begin{array}{l}1000 \text { healthy, } \\
\text { vulnerable and } \\
\text { distressed indus- } \\
\text { trial firms for } \\
\text { 1982-1992. }\end{array}$ & $\begin{array}{l}\text { Neural networks } \\
\text { have potential } \\
\text { predictive abilities } \\
\text { but sensitive to } \\
\text { overfitting. How- } \\
\text { ever, LDA gives } \\
\text { better results. }\end{array}$ \\
\hline Lee et al. (1996) & Financial Ratios & $\begin{array}{c}\text { MDA, Iterative } \\
\text { Dichotomiser } 3 \\
\text { (ID3), Self-orga- } \\
\text { nizing feature } \\
\text { map (SOFM). }\end{array}$ & & \\
\hline $\begin{array}{l}\text { Hybrid models: } \\
\text { MDA-assisted } \\
\text { NN, ID3-assisted } \\
\text { NN, SOFM-assist- } \\
\text { ed NN }\end{array}$ & $\begin{array}{c}83 \text { companies } \\
\text { over 1979-1992. } \\
\text { Matched sample } \\
\text { in terms of size, } \\
\text { capital size, num- } \\
\text { ber of employees, } \\
\text { and age. }\end{array}$ & $\begin{array}{l}\text { SOFM(MDA-as- } \\
\text { sisted) NN } \\
\text { performs better } \\
\text { than other hybrid } \\
\text { and individual } \\
\text { models. }\end{array}$ & & \\
\hline
\end{tabular}




\begin{tabular}{|c|c|c|c|c|}
\hline $\begin{array}{c}\text { Jo and Han } \\
\text { (1996) }\end{array}$ & Financial Ratios & $\begin{array}{c}\text { Discriminant } \\
\text { Analysis, Neural } \\
\text { Network, Case- } \\
\text { based forecasting }\end{array}$ & $\begin{array}{l}\text { 31, } 99 \text {, and } \\
41 \text { bankrupt } \\
\text { firms and the } \\
\text { same number } \\
\text { of non-bank- } \\
\text { rupt firms in } \\
1991,1992 \text {, and } \\
1993 \text { respectively }\end{array}$ & $\begin{array}{l}\text { The predictive } \\
\text { accuracy of an } \\
\text { integrated model } \\
\text { is far greater than } \\
\text { that of individual } \\
\text { models. }\end{array}$ \\
\hline Shumway (2001) & $\begin{array}{c}\text { Financial Ratios } \\
\text { and Equity Mar- } \\
\text { ket Variables }\end{array}$ & $\begin{array}{l}\text { Simple Hazard } \\
\text { model (similar } \\
\text { to multi-period } \\
\text { logit) }\end{array}$ & $\begin{array}{c}300 \text { bankrupt } \\
\text { firms observed } \\
\text { over } 1962-1992\end{array}$ & $\begin{array}{l}\text { The dynamic } \\
\text { model has more } \\
\text { predictive accu- } \\
\text { racy than that of } \\
\text { static models. }\end{array}$ \\
\hline $\begin{array}{c}\text { Bharath and } \\
\text { Shumway (2008) }\end{array}$ & $\begin{array}{c}\text { Equity Market } \\
\text { Variables }\end{array}$ & $\begin{array}{l}\text { KMV-Merton } \\
\text { model, Hazard } \\
\text { model }\end{array}$ & $\begin{array}{c}\text { 1,449 firms over } \\
1980-2003\end{array}$ & $\begin{array}{l}\text { The marginal } \\
\text { benefits of KMV } \\
\text { model come from } \\
\text { its functional } \\
\text { form. KMV-Mer- } \\
\text { ton probability is } \\
\text { marginally useful } \\
\text { default forecaster } \\
\text { but not sufficient } \\
\text { statistics. Moody's } \\
\text { KMV is better } \\
\text { than KMV-Mer- } \\
\text { ton. }\end{array}$ \\
\hline $\begin{array}{l}\text { Pindado et al. } \\
\qquad(2008)\end{array}$ & Financial Ratios & Panel logit model & $\begin{array}{c}1,583 \text { companies } \\
\text { of US and } 2,250 \\
\text { companies for } \\
\text { G-7 countries } \\
\text { over } 1990-2002\end{array}$ & $\begin{array}{l}\text { The panel logit } \\
\text { model has greater } \\
\text { accuracy than the } \\
\text { Altman Z-score } \\
\text { model. }\end{array}$ \\
\hline $\begin{array}{l}\text { Agarwal and } \\
\text { Taffler (2008) }\end{array}$ & Financial Ratios & $\begin{array}{l}\text { Merton's model } \\
\text { with two different } \\
\text { approaches. }\end{array}$ & & \\
\hline
\end{tabular}




\begin{tabular}{|c|c|c|c|c|}
\hline $\begin{array}{l}\text { UK-based Z-score } \\
\text { model }\end{array}$ & $\begin{array}{c}\text { 2,006 non-finan- } \\
\text { cial firms over } \\
1986-2001\end{array}$ & $\begin{array}{l}\text { Both the } \\
\text { market-based } \\
\text { approach } \\
\text { (Merton model) } \\
\text { and account- } \\
\text { ing-based models } \\
\text { (Z-score) capture } \\
\text { different aspects } \\
\text { of bankruptcy. } \\
\text { However, the } \\
\text { accounting-based } \\
\text { approach produc- } \\
\text { es significant eco- } \\
\text { nomic benefits } \\
\text { over others. }\end{array}$ & & \\
\hline $\begin{array}{l}\text { Tinoco et al. } \\
\text { (2015) }\end{array}$ & $\begin{array}{l}\text { Financial Ratios, } \\
\text { Equity Market, } \\
\text { and Macroeco- } \\
\text { nomic Variables }\end{array}$ & $\begin{array}{l}\text { Polytomous } \\
\text { response (three- } \\
\text { state) logit model }\end{array}$ & $\begin{array}{l}21964 \text { non-finan- } \\
\text { cially distressed/ } \\
\text { failed companies, } \\
869 \text { financially } \\
\text { distressed, } 385 \\
\text { failed companies } \\
\text { for } 2012\end{array}$ & $\begin{array}{l}\text { Model-based on } \\
\text { the combination } \\
\text { of accounting, } \\
\text { market, and } \\
\text { macroeconomic } \\
\text { variables have } \\
\text { higher predictive } \\
\text { accuracy than the } \\
\text { individual model } \\
\text { at least for two } \\
\text { lags. }\end{array}$ \\
\hline $\begin{array}{l}\text { Tinoco and Wil- } \\
\text { son (2013) }\end{array}$ & $\begin{array}{l}\text { Financial Ratios, } \\
\text { Equity Market, } \\
\text { and Macroeco- } \\
\text { nomic Variables }\end{array}$ & $\begin{array}{l}\text { Logistic regres- } \\
\text { sion, Altman } \\
\text { Z-score, compre- } \\
\text { hensive neural } \\
\text { network (MLP) }\end{array}$ & $\begin{array}{c}23218 \text { firm-years } \\
\text { observations over } \\
\text { 1980-2011 }\end{array}$ & $\begin{array}{l}\text { The combination } \\
\text { of three types } \\
\text { of variables in } \\
\text { logistic regression } \\
\text { outperforms the } \\
\text { other models. }\end{array}$ \\
\hline Khan (2018) & Financial Ratios & $\begin{array}{l}\text { Multiple Discrim- } \\
\text { inant Analysis } \\
\text { (MDA) and the } \\
\text { logistic regression } \\
\text { model }\end{array}$ & $\begin{array}{c}40 \text { financial } \\
\text { institutions over } \\
2009-2015\end{array}$ & $\begin{array}{l}\text { The logistic re- } \\
\text { gression approach } \\
\text { outperforms } \\
\text { the multiple } \\
\text { discriminant } \\
\text { analysis (MDA) } \\
\text { by achieving } \\
81.5 \% \text { predictive } \\
\text { accuracy. }\end{array}$ \\
\hline
\end{tabular}


Table 9: Initial List of Variables

\begin{tabular}{|c|c|c|}
\hline Type & Variables & Symbol \\
\hline \multicolumn{3}{|c|}{ Market Variables } \\
\hline Market & Adjusted Stock Price & M1 \\
\hline Market & Asset Return & M2 \\
\hline Market & Adjusted Sigma & M3 \\
\hline Market & Size & M4 \\
\hline Market & Market Capitalization to Total Debt Ratio & M5 \\
\hline \multicolumn{3}{|c|}{ Financial variables } \\
\hline Liquidity & Current Ratio & A1 \\
\hline Liquidity & Quick Ratio & A2 \\
\hline Liquidity & Cash Ratio & A3 \\
\hline Liquidity & Working Capital to Total Asset & A4 \\
\hline Liquidity & Working Capital to Total Debt ratio & A5 \\
\hline Liquidity & Sales to Current Asset Ratio & A6 \\
\hline Liquidity & Current Liabilities to Total Liabilities Ratio & A7 \\
\hline Liquidity & Working Capital to Equity & A8 \\
\hline Liquidity & Current Asset to Total Asset & A9 \\
\hline Liquidity & Quick Asset to Total Asset Ratio & $\mathrm{A} 10$ \\
\hline Liquidity & Quick Asset to Inventory Ratio & A11 \\
\hline Liquidity & Cashflow to Short-term Debt ratio & A12 \\
\hline Liquidity & Cashflow to Total Asset Ratio & A13 \\
\hline Leverage & Debt to Equity Ratio & A14 \\
\hline Leverage & Long-term Debt to Equity Ratio & A15 \\
\hline Leverage & Cash Coverage Ratio & A16 \\
\hline Leverage & Funded Capital Ratio & A17 \\
\hline Leverage & Total Debt to Total Asset Ratio & A18 \\
\hline Leverage & Short-term Debt to Total Debt Ratio & A19 \\
\hline Leverage & Long-term Debt to Total Asset Ratio & A20 \\
\hline Leverage & Interest Coverage Ratio & A21 \\
\hline Leverage & Long-term Debt to Equity Ratio & A22 \\
\hline Leverage & Short-term Debt to Equity Ratio & A23 \\
\hline Leverage & Total Debt to Equity Ratio & A24 \\
\hline
\end{tabular}




\begin{tabular}{|c|c|c|}
\hline Profitability & Earnings Before Taxes to Revenues Ratio & A25 \\
\hline Profitability & Net Profit Margin & A26 \\
\hline Profitability & Return on Equity & $\mathrm{A} 27$ \\
\hline Profitability & Return on Asset & A28 \\
\hline Profitability & Return on Capital & A29 \\
\hline Profitability & Operating Profit Margin & $\mathrm{A} 30$ \\
\hline Profitability & Operating Income Margin & A31 \\
\hline Profitability & Gross Profit Margin & A 32 \\
\hline Efficiency & Inventory Turnover Ratio & A33 \\
\hline Efficiency & Asset Turnover Ratio & A34 \\
\hline Efficiency & Cashflow to Total Debt Ratio (Debt Coverage Ratio) & A35 \\
\hline Efficiency & Interest Expense to Debt Ratio & A36 \\
\hline Efficiency & Tax Rate Percentage & A37 \\
\hline Activity Ratio & Net Working Capital to Net Sales & A38 \\
\hline Activity Ratio & $\begin{array}{l}\text { Tangible Fixed Assets Turnover ratio :(net sales/fixed } \\
\text { assets) }\end{array}$ & $\mathrm{A} 40$ \\
\hline Activity Ratio & Long-term Debt Turnover Ratio & A41 \\
\hline Activity Ratio & Quick Asset to Net Sales Ratio & $\mathrm{A} 42$ \\
\hline Activity Ratio & Cash to Net Sales Ratio & A43 \\
\hline \multicolumn{3}{|c|}{ Macroeconomic variables } \\
\hline Macroeconomic & Terms of Trade & E1 \\
\hline Macroeconomic & GDP Growth & E2 \\
\hline Macroeconomic & Money Supply (M2) & E3 \\
\hline Macroeconomic & GDP Deflator & E4 \\
\hline Macroeconomic & Current Account Balance & E5 \\
\hline Macroeconomic & Exchange Rate & E6 \\
\hline Macroeconomic & Forex Reserves & E7 \\
\hline Macroeconomic & Balance of Trade & E9 \\
\hline Macroeconomic & Trade Openness & E10 \\
\hline Macroeconomic & Interest Spread & E11 \\
\hline Macroeconomic & Industrial Production & E12 \\
\hline Macroeconomic & Consumer Price Index & E13 \\
\hline
\end{tabular}


Table 10: Variance Inflating Factor ${ }^{13}$ and Tolerance Value

\begin{tabular}{|c|c|c|c|c|c|c|c|c|}
\hline Variable & VIF & 1/VIF & Variable & VIF & 1/VIF & Variable & VIF & 1/VIF \\
\hline A4 & 614611.19 & 0.00 & A30 & 289.15 & 0.00 & A13 & 1.94 & 0.52 \\
\hline A18 & 614016.63 & 0.00 & A20 & 276.69 & 0.00 & A10 & 1.92 & 0.52 \\
\hline E13 & 305210.56 & 0.00 & A1 & 216.58 & 0.00 & A33 & 1.91 & 0.52 \\
\hline E14 & 166178.64 & 0.00 & A5 & 211.03 & 0.00 & A11 & 1.86 & 0.54 \\
\hline A24 & 137323.98 & 0.00 & A36 & 131.02 & 0.01 & A3 & 1.76 & 0.57 \\
\hline A14 & 124266.91 & 0.00 & A9 & 87.56 & 0.01 & A27 & 1.74 & 0.57 \\
\hline E6 & 58676.33 & 0.00 & A39 & 77.59 & 0.01 & A17 & 1.72 & 0.58 \\
\hline E2 & 6762.91 & 0.00 & A32 & 67.35 & 0.01 & A35 & 1.72 & 0.58 \\
\hline A15 & 4311.32 & 0.00 & A21 & 34.21 & 0.03 & M2 & 1.25 & 0.80 \\
\hline A23 & 3659.63 & 0.00 & A16 & 34.18 & 0.03 & A28 & 1.20 & 0.83 \\
\hline E7 & 3403.06 & 0.00 & A38 & 16.67 & 0.06 & M4 & 1.18 & 0.85 \\
\hline E12 & 2643.82 & 0.00 & A43 & 10.38 & 0.10 & M1 & 1.17 & 0.86 \\
\hline E8 & 1951.18 & 0.00 & A12 & 7.37 & 0.14 & A40 & 1.14 & 0.88 \\
\hline E11 & 1582.10 & 0.00 & A42 & 4.55 & 0.22 & M3 & 1.05 & 0.95 \\
\hline E4 & 1561.54 & 0.00 & A8 & 3.57 & 0.28 & A29 & 1.03 & 0.97 \\
\hline E3 & 1548.09 & 0.00 & A2 & 3.25 & 0.31 & A41 & 1.02 & 0.98 \\
\hline A25 & 1058.78 & 0.00 & A34 & 3.24 & 0.31 & A37 & 1.01 & 0.99 \\
\hline A31 & 729.35 & 0.00 & A6 & 2.60 & 0.38 & & & \\
\hline A26 & 584.82 & 0.00 & A7 & 2.58 & 0.39 & & & \\
\hline E1 & 324.26 & 0.00 & M5 & 2.44 & 0.41 & & & \\
\hline
\end{tabular}

13 VIF is calculated as:

$V I F_{i}=\frac{1}{1-R_{i}^{2}}$

where Ri2 is the coefficient of determination when ith independent variable is regressed over others. Tolerance value is simply the reciprocal of VIF. 